Leading article/Uvodnik

\title{
Critical issues in nursing education in Croatia
}

\author{
Pereči problemi izobraževanja na področju zdravstvene nege na Hrvaškem
}

\author{
Sonja Kalauz
}

Taking into consideration the latest guidelines of the education strategies (Directive 2005/36/EC and Directive 2013/55 EC) the focus of nursing education needs to be placed on acquisition of knowledge and skills which refer to: recognition of health needs of individuals and the community/society; ways and models of communication and collaboration with other health workers (teamwork) and health and social institutions; developing partnership with the patients, other people and targeted groups. The education system should prepare nurses not just for the application of what has been learned - more precisely, for administering nursing care, health promotion and disease prevention - but for a continuous monitoring and quality control of executed work.

Today nursing is mostly spoken of and written about as a highly-developed profession with its own regulations and legislation, its own identity, autonomy and wellorganized professional associations. In sociology the term profession is defined as an occupation which has a monopoly on expertise in a particular area, and which requires long-lasting education ending at doctoral level and is recognized as such in the society (Štifanić, 2012).

The most important aspect of professionalisation is achieving as high a level of independence as possible, development of scientific work and correlation of theory and practice, but also the development of skills and knowledge which the society will recognize as the fundamental characteristic of a specific profession and as something it requires.

It is precisely in that area that nurses are faced with numerous difficulties. Strong professionalisation in health institutions constantly imposes the need for clear professional demarcation in the area of professional and moral responsibility, autonomy and competences.

This problem is particularly noticeable in the relationship between doctors and nurses and the differences in their views, attitudes, mind set and interpretation (Matulić, 2007).

Key nursing reformers (Bradshaw, 2011) have always been aware of the fact that a good educational system enables achieving high standards of excellence and diminishes the gap in the perception of the value of each respective profession.

These issues have become particularly prominent after Croatia gained independence, where a fouryear war significantly determined the characteristics of a new social order as well as the dynamics of such change (Kalauz, 2011). The changes in the educational system in the 1990s also affected nursing and they were marked by political, ideological and institutional deconstruction of socialist educational system, which was not implemented according to systematic curricula-guidelines or adopted strategic documents. The period after 2000 was marked by a process of Europeanization of national educational policy which was 'characterized by implementing changes with new benchmarks and new strategic documents based on the current European educational goals' (Žiljak, 2005). In the field of nursing education key changes have occurred, the consequences of which are still present today. The introduction of Bologna process in Croatia started in 2001, but it was only in 2005 that all study programmes were harmonised according to its principles. That same year a binary model of education was introduced which implied the organization and implementation of professional studies (at polytechnics and universities of applied sciences) and university studies. Nursing education remained at a professional level which prevented vertical mobility to doctoral level. General nursing study programmes, regardless of where they are carried out, should have met the minimal standards of the Directive 2005/36 EC (at least three years of study, 4,600 teaching hours, out of which $50 \%$ comprised practical training and $2 / 3$ of content related to the field of nursing (Annex 5). Even though content regulated by the Directive equates university and professional studies, binary education system in Croatia has and still discriminates against the students of professional nursing study 
programmes because those students cannot continue their studies at university graduate level, much less at doctoral level.

For that reason, in 2011, Split and Osijek School of Medicine introduced university undergraduate and graduate nursing studies, and Zagreb School of Medicine introduced a university graduate study programme (Romac, 2005). That same year a five-year secondary education for general nurses was introduced $(2+3$, after eight years of primary education), whose content was in accordance with the Directive 2005/36 EC and Directive 2013/55 EU which recommend:

- 12 years of general education attested by a diploma, certificate or other evidence issued by the competent authorities or bodies in a Member State, or a certificate attesting success in the exam of an equivalent level and which provides access to universities or equivalent institutions of higher education, or

- at least ten years of general education attested by a diploma, certificate or other evidence issued by the competent authorities or bodies in a Member State, or a certificate attesting success in the exam of an equivalent level and which provides access to vocational school or a vocational training programme in nursing.

This duality of the Directives encourages different interpretations, which in turn allows some European Union (EU) member states to have a wider framework for creating nursing education policy. Consequently, some countries may introduce programmes that meet the minimal standards of education, but in the long term certainly harm the nursing profession, and in particular the level of quality of nursing care.

When comparing the minimal standards of the Directive 2005/36 with the competences regulated by the Directive 2013/55 EC - such as the competences to: independently diagnose nursing care required using current theoretical and clinical knowledge; plan, organise and implement nursing care when treating patients; independently assure the quality of, and evaluate nursing care; work together effectively with other actors in the health sector; participate in practical training of health worker; professionally communicate and cooperate with members of other professions in the health sector; empower individuals, families and groups towards healthy lifestyles and self-care based on acquired knowledge and skills - it is evident that allowing access to nursing profession after completing ten years of general education at vocational schools or vocational training programmes in nursing care - will not contribute to the development of the aforementioned competences.

The lack of precisely defined standards in the educational vertical structure in any profession, including the nursing profession, puts to the test all other processes of professionalisation (development of scientific work and research, scientific field autonomy, social recognisability and class-equality), but also a recognisability in terms of organizational structure needs in health institutions. As long as the unique educational entry level to nursing profession and clear educational vertical structure enabling education at doctoral level are not defined, and until the need for well-educated nurses employed at clearly defined positions at all levels of scientific and health institutions is recognized submissiveness will remain the expected behaviour pattern of nurses.

\section{Literature}

Bradshaw, A., 2011. The future of clinical nursing: meeting the needs of patients for compassionate and skilled nurses. Journal of Clinical Nursing, 20, pp. 1797-1800.

Directive 2005/36/EC of the European Parliament and of the Council of 7 September 2005 on the recognition of professional qualifications (Text with EEA relevance). Available at: www. http://eur-lex.europa.eu/LexUriServ/LexUriServ.do?uri=OJ:L: 2005:255:0022:0142:en:PDF [13. 5. 2014].

Directive 2013/55/EU of the European Parliament and of the Council of 20 November 2013 amending Directive 2005/36/EC on the recognition of professional qualifications and Regulation (EU) No 1024/2012 on administrative cooperation through the Internal Market Information System ('the IMI Regulation') (Text with EEA relevance). Available at: http://eur-lex.europa.eu/ LexUriServ/LexUriServ.do?uri=OJ:L:2013:354:0132:0170:en:P DF [13. 5. 2014].

Kalauz, S., 2011. Nursing profession in light of bioethical pluriperspectives. Pergamena, pp. 203 - 223.

Matulić, T., 2007. Nursing identity, profession and ethics [in Croatian]. Bogoslovska smotra: Ephemerides Theologicae Zagrabienses, 77(3), pp. 727-44.

Romac, D., 2005. The Bologna Declaration [in Croatian]. Zagreb: Ekscentar, Student Assembly of the University of Zagreb, Faculty of Geometry, 7, pp. 10-11.

Štifanić, M., 2012. What do nurses do at university? What types of nurses do we need? [in Croatian], Rijeka: Association for Patient Rights (HPPP).

Žiljak, T., 2005. Lifelong learning policy in the European Union and Croatia. [in Croatian]. Političko obrazovanje, 1(1), pp. 67-95. 